\title{
Dipeptidyl Peptidase IV (DPP-IV) Inhibitory Activity of Ultrafiltration and Gel Filtration Fraction of Gelatin Hydrolyaste Derived from Bone of Fish for Antidiabetes
}

\author{
Yoni Atma ${ }^{\#}$, Hanifah Nuryani Lioe* ${ }^{*}$ Endang Prangdimurti ${ }^{*}$, Hermawan Seftiono ${ }^{\#}$, Moh. Taufik ${ }^{\#}$, \\ Apon Zaenal Mustopa \\ ${ }^{\#}$ Department of Food Science and Technology, Faculty of Bioindustry, Universitas Trilogi, Kalibata, Jakarta, 12760, Indonesia \\ E-mail:yoniatma@trilogi.ac.id (corresponding author); hermawan_seftiono@trilogi.ac.id; taufikmoh87@gmail.com \\ *Department of Food Science and Technology, Faculty of Agricultural Engineering and Technology, Bogor Agricultural University, IPB \\ Darmaga, Bogor, 16680, Indonesia \\ E-mail:hanifahlioe@apps.ipb.ac.id; e_prangdimurti@yahoo.com
}

${ }^{\wedge}$ Research Center for Biotechnology, Indonesian Institute of Science, Cibinong, Bogor, 16912, Indonesia

E-mail:azmustopa@yahoo.com

\begin{abstract}
Bioactive peptides have been investigated largely for many biofunctional properties. The aim of this research was to determine the inhibitory activity of ultrafiltration (UF) and gel filtration (GF) fractions of gelatin derived from bone of Pangasius catfish against dipeptidyl peptidase IV (DPP-IV). Previous studies have shown that gelatin from skins of salmon, hake, halibut, milkfish, tilapia and bone of pangasius catfish have the activity in DPP-IV inhibition. While, as inhibitor, most of previous and recent studies shown that separation and fractination of gelatin hydrolysate increase their activity. This research was conducted in three stages including gelatin hydrolysates fractination by ultrafiltration (UF), UF fraction loaded into gel filtration (GF) and DPP-IV inhibition measurement. The fish bone gelatin was hydrolyzed using flavourzyme at three enzyme/substrate ratios (E/S of 3\%, $6 \%$ and $9 \%$ ) with incubation times 4,6 , and $8 \mathrm{~h}$. Then, the hydrolysates fractioned by ultrafiltration with $3 \mathrm{kDa}$ cutoff membrane continued with Superfine G-25 sephadex column $(65 \mathrm{~cm} \times 3 \mathrm{~cm}$, flow rate $1 \mathrm{~mL} / \mathrm{min})$. The result shown that both group of fractions i.e UF and GF have inhibitory activity regarding their capacity to inhibit DPP-IV. The UF fraction $>3 \mathrm{kDa}$ derived from $9 \%$ (E/S) ratio for hdyrolysis were superb as DPP-IV inhibitor than other fractions, the highest one also has bioactivity higher than other previous fish gelatin fractions.
\end{abstract}

Keywords - dipeptidyl peptidase-IV inhibitor; fish gelatin; antidiabetes type 2; incretin; bioactive peptide.

\section{INTRODUCTION}

Bioactive peptides is specific protein fragments (usually range from 2 to 20 amino acid residues) that acting as sources of amino acids sequence with numerous potential physiological functions including opioid, antioxidant, immunomodulatory, antibacterial, antithrombotic and antihypertensive activity [1]. Now, it has been investigated largerly for other biofunctional properties, such as anticancer [2] and antidiabetes [3]. As antidiabetes, most of studies have been concern to the activity of bioactive peptide contra dipeptidyl peptidase IV (DPP-IV) [4], [5]. DPP-IV is an enzyme degrades glucose-dependent insulinotropic polypeptide (GIP) and glucagon-like peptide-1 (GLP-1), which are both of them is a precusor for creating incretin.
The degradation of GIP and or GLP-1 causes the incretin loses their fuction, while this hormone has a significant aspect related managing of blood glucose homeostasis, and it was encouraging in therapeutic target of type 2 diabetic (T2D) treatment and prevention [3], [6], which is most of T2D has been focused on incretin regulation as a novel therapy, recently [7]. In addition, majority of diabetes patient is T2D (more than 90\% diabetic patients is affect T2D [8]) and some of drugs for treating T2D by incretin approach have been trade commercially [9]. So that why, currently, research and study related producing and characterizing of bioactive peptide as inhibitor of DPP-IV have been increase dramatically.

The bioactive peptides as DPP-IV inhibitor has been inspected from broad sources, like microbial product and 
natural food protein [4]. Diprotin A and B, a microbial bioactive peptide provide supreme inhibitory activity toward DPP-IV [10], regardless the utilization of food based protein as parent of bioactive peptide is a favorable choice, paticularly for safety and health consideration. The food based protein that have been used to produce of bioactive peptide covering chiken egg, beef meat, soy protein, cheese, milk, corn, fish meat and gelatin [1], [4], [11]. We definitely agreed that gelatin is the most promosing source of bioactive peptide including for DPP-IV inhibitor. Despite, it has been used widely in food, phramaceutical and cosmetic products, fortunately, gelatin usually extracted from by-product or useless materials [12],[13]. In addition, the inhibitory activity of bioactive peptide againts DPP-IV influence by their proline existency, whilst this amino acid is second abundance in gelatin [5].

Number of studies have been done by using of gelatin as source of bioactive peptide for DPP-IV inhibitor. Almost all type of gelatin sources have shown inhibitory activity against DPP-IV covering traditional and alternative origin [14], [15], [16]. Even though, most of gelatin or derivates is from mammalians, such as cow and pig [17], but some research were used gelatin from alternative source in order to seeking a bioactive peptide for DPP-IV inhibitor [15], [16], [18], [19]. It is caused by socio-religion and cultural aspects, where are gelatin derived from porcine is unacceptable in Muslim and Jewish communities, whereas bovine or cow gelatin is not accepted by Hindu community [20]. The gelatin from alternative sources which has been tested for generating bioactive peptide as DPP-IV inhibitor monopolized by fish gelatin. They were involved gelatin from skin of salmon [18], [19] hake, halibut, milkfish, nila tilapia [16] and pangasius catfish [15]. Bioactive peptide derived from warm-water fish were higher than other in order to inhibit DPP-IV action [16].

The bone of Pangasius catfish was most auspicious as source of gelatin and their derivatives. This type of fish was was confirmed that they was provided highest in gelatin yield, camparable in physical characterictics within commercial gelatin and they have ash content which is confirm with standard of gelatin [21], [22]. In Indonesia, Pangasius catfish spread out in Sumatera and Borneo island, where are their consumption and production rate has been increased continuously every years. The Ministry of Marine Affairs and Fisheries of Indonesia was targeted the Pangasius catfish production in 2018 reaching 604.587 ton [23], it would inflicted to they waste especially bones, which is contribute about $12.44 \%$ for total fish weight. In addition, our previous study also shown that the gelatin from bone of Indonesia Pangasius catfish has DPP-IV inhibitory activiy, and it was above of bovine and fish skin gelatin activities [15]. Consequently, it is required to further analysis of this gelatin hydrolysate in order to discover a superior and sustainable source of bioactive peptide with DPP-IV inhibitory activity.

The aim of this research was to determine the inhibitory activity of ultrafiltration (UF) and gel filtration (GF) fractions of fish bone of gelatin hydrolysate against DPP-IV. It is because most of previous studies were described that the inhibitory activity increased after the separation and fractionation. Although, the activity might be scale down on
GF fraction coincide with their protein reduction, however this process is needed in order to obtain the pure component or peptide sequence as well as to increase the spesific activity. For functional food and drug agents, the high activity with the lower concentration is necessary.

\section{MATERIAL AND METHOD}

\section{A. Materials and Reagents}

The gelatin solution from bone of Pangasius catfish (Pangsius sutchi) which was extracted on our previous study [15]. The Hydroxyproline Colorimetric Assay Kit (containing $10 \mathrm{~mL}$ Oxidation buffer, $0.6 \mathrm{~mL}$ Chloramin $\mathrm{T}$ concentrate, $5 \mathrm{~mL}$ Perchloric acid/Isopropanol solution, 5 $\mathrm{mL}$-dimethylaminobenzaldehyde (DMAB) concentrate (in DMSO) and $0.1 \mathrm{~mL}$ Hydroxyproline standard) was purchased from Biovision Inc. (Milpitas, CA, USA). The food-grade proteolytic enzyme, Flavourzyme $250 \mathrm{~mL}$ (from Aspergillus oryzae, $500 \mathrm{U} / \mathrm{g}$ ) was manufactured by Novozyme Corp. (Bagsvaerd, Denmark). Dipeptidyl Peptidase IV human (D4943, expressed in baculovirus infected $S f 9$ cells), Gly-pro-p-nitroanilide, Bovine serum albumin (BSA), Superfine sephadex G-25 and Diprotin A were purchased from Sigma Aldrich (St. Louis, MO, USA). Sitagliptin phosphate monohydrate was from European Pharmacopoeia (Strasbourg, France). The Citric acid and Trichloro acetic acid (TCA) were donated by Merck KgaA (Darmstadt, Germany). Marker proteins was purchased from Promega Cooperation (Madison, WI, USA). Other chemicals and reagents used were of analytical grade and it is available commercially.

\section{B. Gelatin Confirmation Test}

Before hydrolysis the gelatin existance was confirmed by sodium dodecyl sulfate polyacrylamide gel electrophoresis (SDS-PAGE) through discontinues Tris/HCl/ glycine buffer system [21]. A $20 \mu \mathrm{L}$ liquid solution of fish bone gelatin loaded into gel on electrophoresis apparatus (ATTO, Tokyo, Japan), running at voltage of $50 \mathrm{~V}$ for $90 \mathrm{~min}$. During this anaysis, marker protein was also loaded as standard of molecular weight range. Then, the gelatin yield calculated as the ratio of weight dried fish bone gelatin to the total weight of leached bone (ossein) on wet basis [21]. Finally, the hydroxyproline recovery analyzed as extraction yield and selected as part of indicator of gelatin amount. It was calculated by the method described in Koli et al. [24] and Atma et al. [25] with some modifications.

\section{Gelatin Hydrolysis}

In the hydrolysis stage, the fish bone gelatin was incubated at $50{ }^{\circ} \mathrm{C}$ for 10 minutes prior enzymatic hydrolysis. The hydrolysis reaction was started by the addition of Flavourzyme at various enzyme/substrate ratios (E/S: 3, 6 and $9 \%$ ) and incubation times (4, 6 and 8 hours). The hydrolysis process was stopped by heating the reaction in the boiling water $\left(100{ }^{\circ} \mathrm{C}\right)$ for 10 minutes and cooled in ice water for 20 minutes immediatelly, both for enzyme inactivation. Then, adjusted to $\mathrm{pH} 7.0$ with addition of $1 \mathrm{M}$ $\mathrm{NaOH}$ and centrifugated (Hettich, Tuttlingen, Germany) at $10.000 \mathrm{~g}, 4{ }^{\circ} \mathrm{C}$ for 15 minutes. The supernatant or gelatin hydrolysate was collected and stored at $-18{ }^{\circ} \mathrm{C}$. The degree 
of hydrolysis (DH) measured by quantify of remain protein in hydrolysate divided total protein in gelatin (whitout hydrolysis) as adopted from Mahmoodani et al. [26] which is using 20\% Trichloroacetic acid (TCA) (w/v) to allow precipitation, Bradford solution (commasie brilliant blue G250:ethanol :phosphoric acid; 2:1:2; w/v/v) to protein quantification and Bovine serum albumin $(0.1-1 \mathrm{mg} / \mathrm{mL})$ to determine standard qurve.

\section{Ultrafiltration $(U F)$}

The fish bone gelatin hydrolysates were fractionated by ultrafiltration (PLBC Ultracel-PL Millipore, Merck KGaA, Darmstadt, Germany) with vertical regenerated cellulose membrane having molecular weight cut-off $3 \mathrm{kDa}$ combined centrifugation at $4000 \mathrm{~g}$ and $4{ }^{\circ} \mathrm{C}$ for 45 minutes. The fraction was collected as follow: $>3 \mathrm{kDa}$, hydrolysates retained without passing through $3 \mathrm{kDa}$ membrane and $\leq 3$ $\mathrm{kDa}$, hydrolysates permeating through the $3 \mathrm{kDa}$ membrane. All fractions namely UF fractions were collected and stored in refrigerator until further analysis and fractination.

\section{E. Gel Filtration $(G F)$}

The UF fraction which has highest activity as a DPP-IV inhibitor was fractionated using a gel filtration column. A 5 $\mathrm{mL}$ fraction solution was loaded in a column $(65 \mathrm{~cm} \times 3 \mathrm{~cm})$ containing a stationary phase of the G-25 sephadex gel. The column was equiliberated prior of fraction loading by using aquabides (mobile phase). When the UF fraction solution entered the stationary phase, then aquabides added again. Samples and mobile phases passing through the column at a speed of $1 \mathrm{~mL} / \mathrm{min}$ are manually collected with a test tube per $5 \mathrm{~mL}$ expressed as sub-fractions. Furthermore, each protein profile was measured using a spectrophotometer at wavelengths $214 \mathrm{~nm}$ and $280 \mathrm{~nm}$. Based on this protein pattern, subfractions are then mixed into several fractions to measure their activity as DPP-IV inhibitors.

\section{F. Determination of DPP-IV Inhibitory Activity}

Inhibitory activity of UF and GF fractions were measured based on their capacity to inhibit DPP-IV in order to use subtrate i.e Gly-Pro-p-nitroanilide [27]. It was performed using microplate reader (Multiscan Ex, Champaign, IL, USA) mated with 96-well microplate and interpreted by the color amplification of reacted solution absorbance at visible wavelength [5]. The procedure of analysis is according to our previous study [15]. In this quantification, Sitagiliptin in concentration of $0.1 \mathrm{ng} / \mathrm{mL}$ (diluted with $100 \mathrm{mM}$ buffer Tris, $\mathrm{pH} 8$ ) and $10 \mu \mathrm{g} / \mathrm{mL}$ Diprotin A were used as standard.

\section{G. Statistical Analysis}

The recorded data which represent the average of replication were subjected to an one-way analysis of variance (ANOVA), and Tukey's HSD (Honestly Significant Different) or Tukey's studentized range test was ensued subsequently in order to rule the significant level of $p<0.05$ between data in statistically.

\section{RESULT AND DISCUSSION}

\section{A. The Fish Bone Gelatin from Pangasius catfish}

The gelatin existance in clear exracted solution was confirmed through the molecular weight (MW) range recognition using SDS-PAGE, also the hydroxyproline content and the gelatin yield. It is re-play as same as our previous research [15], [23], [25], but it is needed to be retest in order to justify that the gelatin are presence in the extracted solution. The protein pattern of fish bone gelatin showed at Figure 1. with MW of $>245 \mathrm{kDa}$ and $100-140 \mathrm{kDa}$. The hydroxyproline and gelatin yield are $12.90 \pm 1.03 \mathrm{mg} / \mathrm{g}$ and $5.11 \pm 0.02 \%$ respectively. These three indicators have been sufficient in justify that the extraction process was fruition.

The gelatin has three form; $\alpha$-chain gelatin (with MW $\sim 120 \mathrm{kDa}$ ) , $\beta$-chain (dimer of $\alpha$-chain, MW $\sim 250 \mathrm{kDa}$ ) gelatin and $\mathrm{Y}$-chain (trimer of $\alpha$-chain, $\mathrm{MW}>250 \mathrm{kDa}$ ) gelatin. Gelatin derived from fish bones were dominated by $\beta$ and $\alpha$ form. The $\alpha$-chain gelatin is divided to $\alpha 1$ and $\alpha 2$ form whereas MW of $\alpha 2$ is smaller than $\alpha 1$ [28]. Previous studies have been confirmed that gelatin from bones of Pangasius catfish [21], Lizardfish [29], Grass carp [30], Red snapper and Grouper fish [17], King Weakfish [28] as well as Channel catfish [31] have MW in range of $\beta, \alpha 1$ and $\alpha 2$ chain through vertical electrophoresis identification. Furthermore, our previous studies also found that gelatin extracted from bone of Indonesian Pangasius catfish has shown their band in area with MW of 100-200 kDa and > $225 \mathrm{kDa}$.

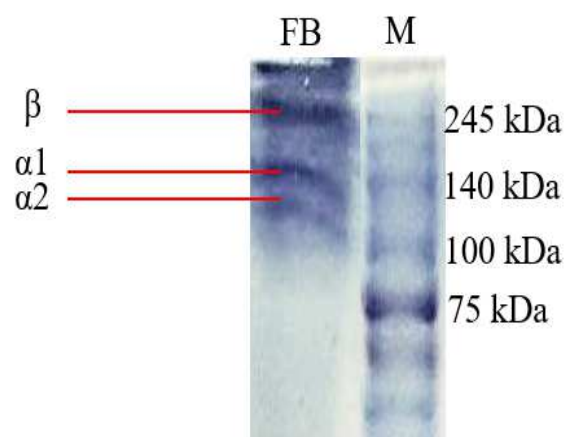

$25 \mathrm{kDa}$

Fig. 1 Electroforegram fish bone gelatin from Pangasius catfish (FB) and marker protein (M)

The next indicators were hydroxyproline concent and the gelatin yield. Hydroxyproline is amino acid which abundant in gelatin and it has a role as differentiator during analyisis in order to describe of this type of protein compared another, despite it was a main factor that influencing of gelatin physical characteristic. The hydroxyproline content in Indonesian Pangasius catfish extracted by pineapple liquid waste with different pre-treatment times was $10.9-16.3$ $\mathrm{mg} / \mathrm{g}$ [12] and extracted by citric acid was $18.1 \mathrm{mg} / \mathrm{g}$ [23]. Hydroxyproline contents of the gelatin derived from bone of Tiger-toothed croaker (Otolithes ruber), Pink perch (Nemipterus japonicus) [24] and skin of Tilapia [32] were $7.51,7.41$ and $8.44 \mathrm{mg} / \mathrm{g}$, respectively. In addition, the gelatin yield was quantified to indicate of resulting dry gelatin based on weigth of bone. Fish bone gelatin yield have been reported to vary among difference species, Tigertoothed croaker was $4.57 \%$, Pink pearch of $3.55 \%$ [17], 
Pangasius catfish was $13.86 \%$ [21], Red snapper was 9.14\% [24], Lizardfish of 8.9\% [29], Channel catfish of 8.43\% [31], and Nila tilapia of $2.4 \%$ [33]. For production of biopolymer, the gelatin yield is important, however for medical use, the bioactivities and protein concentration are essential.

\section{B. Hydrolysate Gelatin Preparation Before Fractination}

Hydrolysis of fish bone gelatin was by enzymatic hydrolysis using Flavourzyme, a protease (exo- and endopeptidase complex) which has been proven produce bioactive peptide with higher bioactivities against DPP-IV. Degrees of Hidrolysis (DHs) were measured on one representative enzyme/substrate $[\mathrm{E} / \mathrm{S}]$ concentration and incubation time. It was confirmed that the fish bone gelatin hydrolyzed through each ratio of concentration. The DHs of the gelatin hydrolysates obtained by all concentration were increased with the increment of $\mathrm{E} / \mathrm{S}$ ratio. The $\mathrm{DH}$ of hydrolysate with $\mathrm{E} / \mathrm{S}$ ratio 3,6 , and $9 \%$ at 4 hours incubation were $31.13 \pm 0.6,43.60 \pm 2.5$ and $59.32 \pm 3.6 \%$, respectively. These values were significant different each other ( $\mathrm{p}<0.05)$. DHs of fish bone gelatin for 4 hours incubation are shown in figure 2 .

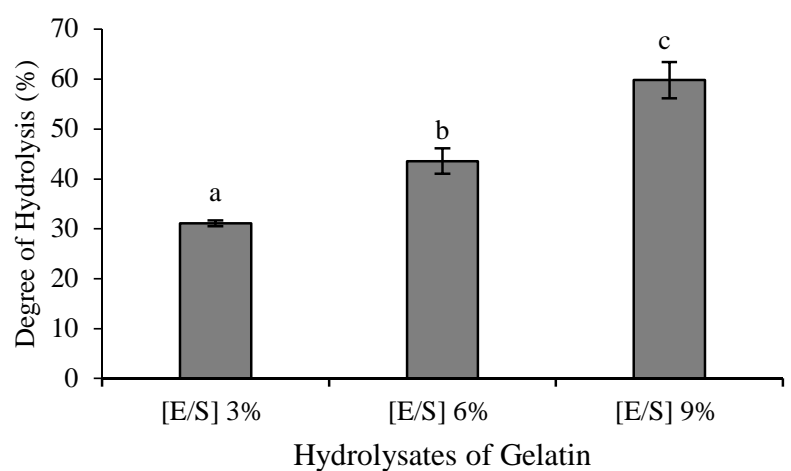

Fig. $2 \mathrm{DH}$ of Pangsius catfish bone gelatin hydrolyzed with Flavourzyme at various E/S ratios during 4 hours incubation time.

DH of hydrolysates derived from tuna juice were 19.4 and $23.6 \%$ by enzyme Protease XXIII (from Aspergillus melleus) and Orientase $9 \mathrm{~N}$ (from Bacillus subtilis) respectively during 6 hours incubation time at E/S ratio of 3.68\%. These hydrolysates having inhibitory activity against DPP-IV of 39.5 and $38.8 \%$ respectively [34]. Study conducted by LiChan et al. shown that $\mathrm{DH}$ of fish skin gelatin using $1 \%$ Flavourzyme (E/S ratio) was $28.3 \%$, it is lower than Alcalase and Bromelin, and at E/S ratio 6\%, the DH was slightly higher than other comparative enzymes which was reached of $42.5 \%$ and it was produced hydrolysate with higher inhibitory activity toward DPP-IV. Patent WO 2006/068480 has demonstrated that protein hydrolysates with DHs of $20-40 \%$ were possessed referrable and preferable for DPP-IV inhibitory activities [19]. Liu et al. stated that the DPP-IV activity is determine by the molecular size or structure and hydrolysate sequences [35], not depend on the DHs.

The extracted fish bone gelatin (without hydrolysis) showed that the percent of inhibition against DPP-IV about $8.37 \%$. Our previous study has been shown that fish bone has a percent inhibition in range of $18.2-21.8 \%$ through 10 1000 times smaller Sitagliptin (standard) concentration compared this study. In this work, the hydrolysate from $9 \%$
E/S ratio along 4 hours incubation showed percent of inhibition of $80.41 \%$, and it was the greatest percent of inhibition toward DPP-IV than other E/S ratio. It is only difference of $20 \%$ compared $0.1 \mathrm{ng} / \mathrm{mL}$ Sitagliptin as positive control. Hydrolysates from $\mathrm{E} / \mathrm{S}$ ratio of $3 \%$ with incubation time 4 hours and 6 hours also having percent of inhibition above of fifty percent which are $51.15 \%$ and $58.72 \%$, respectively, and those no significant different $(\mathrm{p}<$ 0.05 ). Percent of inhibition hydrolysate by E/S ratio of $6 \%$ for 4 hours incubation was $41.38 \%$, and it was declined slowly by the increasing of hydrolysis time. In this study, concluded that the reaction for hydrolysis preferable at 4 hours. In overall, hydrolysis process was gradually increase the value of percent of inhibition on fish bone gelatin.

Previous studies were shown that the inhibition rate of hydrolysate gelatin derived from skin of salmon, halibut, hake, tilapia and milkfish were increased significantly than before hydrolysis. Those were about $10 \%$ or below before enzymatic hydrolysis, whilst after hydrolysis with Flavourzyme, they have inhibitory activity above of $20 \%$ in average and became reach a peak in $48.1 \%$. Hydrolysates gelatin from skin of salmon were above of $40 \%$ by E/S ratio of 1,2, 3 and $6 \%$ at 4 hours incubation [19]. Hydrolysates gelatin from skin of halibut and hake were around of $20 \%$, $30 \%$ and $40 \%$ in inhibition activity for 4 hours incubation at $\mathrm{E} / \mathrm{S}$ ration 1,3 and $5 \%$ respectively. They inhibition rate were stable at various of hydrolysis times (4, 6 and 8 hours). In addition, hydrolysates gelatin from skin of tilapia and milkfish were around mean of $30 \%, 40 \%$ and $45 \%$ for inhibit the DPP-IV activity by same ratio of E/S namely 1,3 and $5 \%$ respectively. The inhibitory acitivity those fish based gelatin were also remain stable at difference incubation period (4, 6, and 8 hours) [16]. All of those previous research were used Diprotin A as standard, however this study was used Sitagliptin as a standard DPPIV inhibitor. Nongonierma and FitzGerald was used 0.006 and $0.03 \mathrm{ng} / \mathrm{mL}$ sitagliptin previously as standard in determination inhibitory activity drug interaction with whey hydrolysate against DPP-IV [36]. Actually, the value of $\mathrm{IC}_{50}$ of Sitagliptin is better namely $\sim 20 \mathrm{nM}$ [37], whilst the $\mathrm{IC}_{50}$ of Diprotin A is $24.7 \mu \mathrm{M}$ [19].

Before fractination, the protein identification was done by SDS-PAGE to ensure that the gelatin hydrolysate is exist in the solution and not totally degraded. It is critical because in the fractination stage, the gelatin hydrolysate is separated and fractionated to become smaller molecule. The activity of fraction is potentially disappear if the procedure of this stage is improperly means that the bioactive peptide is uncollected. Fig. 3 depicted that the fish bone gelatin before hydrolysis and after hydrolysis. Based on Fig. 3 shows that the distribution pattern of gelatin from bone of pangasius catfish is changing, where are around $100-225 \mathrm{kDa}$ before hydrolysis to become $\leq 50 \mathrm{kDa}$ after hydrolysis. It is mean that the hydrolysis stage has been successful whitout eliminate the gelatin. This identification also to confirm the data in Fig. 2. 


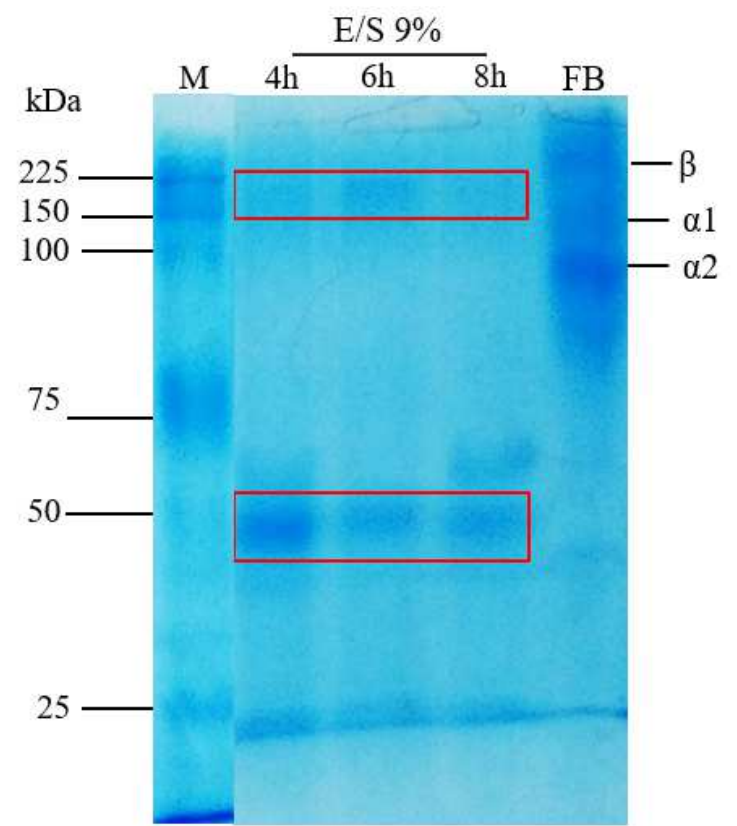

Fig. 3 Electroforegram fish gelatin hydrolysate derived from E/S ratio of $9 \%$ for 4,6 , and $8 \mathrm{~h}$ hydrolysis time. $\mathrm{M}=$ marker protein, $\mathrm{FB}=$ fish bone gelatin (whitout hydrolysis)

\section{DPP-IV Inhibitory Activity of UF fraction}

Inhibition rate of UF fraction $(\leq 3 \mathrm{kDa}$ and $>3 \mathrm{kDa})$ hydrolysates from fish bone gelatin are shown in Fig. 4 and Fig. 5. Fig 4 illustrates percent of inhibition UF fraction of each hydrolysates (in various of $\mathrm{E} / \mathrm{S}$ ratio and time of hydrolysis), and Fig 5 depicts percent of inhibition accompanied with hydroxyproline concent of UF fraction which are highest in their own E/S concentration ratio. The result showed that percent of inhibition of the fraction $>3$ $\mathrm{kDa}$ higher than those fraction $\leq 3 \mathrm{kDa}$. For UF fractions of $>3 \mathrm{kDa}$, percent of inhibition were climbed up moderatly by the increasing of E/S ratio, while for UF fractions of $\leq 3$ $\mathrm{kDa}$ from different $\mathrm{E} / \mathrm{S}$ ratio and hydrolysis time were categorized as stable in DPP-IV inhibition. The fractions $\leq 3$ $\mathrm{kDa}$ have percent of inhibition between $4.51 \pm 0.86$ to $8.36 \pm 0.92 \%$ with insignificant differences $(\mathrm{p}<0.05)$. The fraction $>3 \mathrm{kDa}$ had percent of inhibition of $25.48 \pm 1.92$ $84.83 \pm 12.38 \%$. There were significant different among UF fraction from $\mathrm{E} / \mathrm{S}$ ratio 3, 6 and $9 \%$. The highest percent of inhibition is UF fraction $>3 \mathrm{kDa}$ from E/S ratio $9 \%$ and 4 hours hydrolysis. It was insignificant compared fraction $>3$ $\mathrm{kDa}$ from E/S ratio 9\% and 6 hours hydrolysis. Fig. 5 shows that no correlation between hydroxyproline content and inhibitory activity of fraction gelatin. UF fraction $\leq 3 \mathrm{kDa}$ contain hydroxyproline $70-97.27 \mathrm{mg} / \mathrm{g}$, and UF fraction $>3$ $\mathrm{kDa}$ have hydroxyproline 81.36 - $160.91 \mathrm{mg} / \mathrm{g}$. According to Nongonierma and FitzGerald, inhibitory activity of peptide against DPP-IV is depend on amino acid Proline and Alanin existency [5].

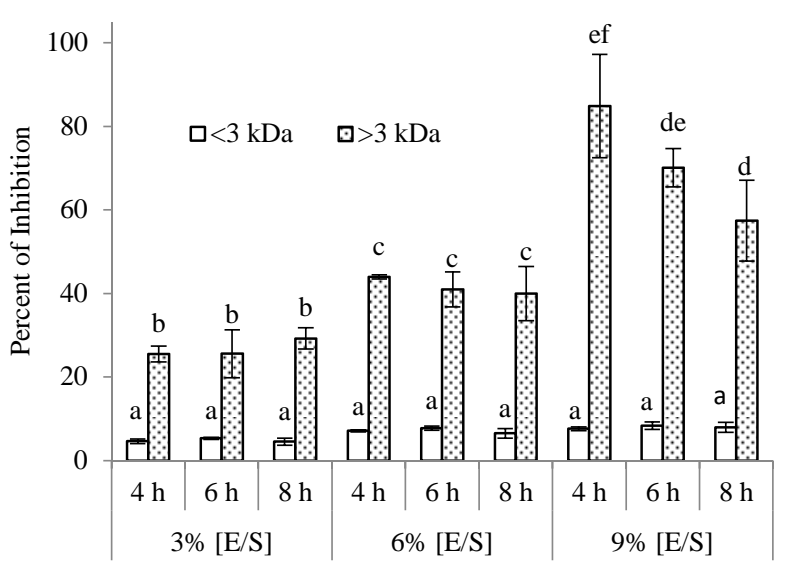

Fish Bone Gelatin Hydrolysates

Fig. 4 Percent of inhibition UF fractions of gelatin derived from bone of Pangasius catfish against DPP-IV. The percent of inhibition was determined by using Sitagliptin $(0.1 \mathrm{ng} / \mathrm{mL})$ as standard. Bars with different letters are significantly different at $\mathrm{p}<0.05$.

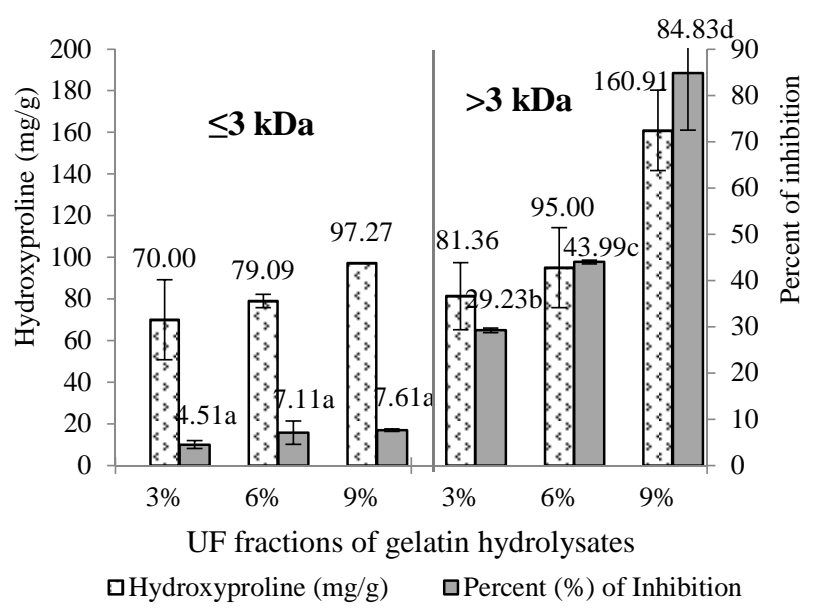

Fig. 5 Percent of inhibition and hydroxyproline concent of UF fraction ( $\leq 3$ $\mathrm{kDa}$ and $>3 \mathrm{kDa}$ ) derived from hydrolysates gelatin of different E/S ratio. Hydroxyproline quantified using hydroxyprolin assay kit, with standard ranging of $0.2-1 \mu \mathrm{g} / \mathrm{mL}$. The percent of inhibition toward DPP-IV was determined by using $0.1 \mathrm{ng} / \mathrm{mL}$ Sitagliptin as standard. Bars with different letters are significantly different at $\mathrm{p}<0.05$.

Study conducted by Li-Chan et al., Huang et al., and Wang et al. showed that the inhibitory activity of fish gelatin hydrolysates facing DPP-IV were higher after ultrafiltration. The peptides of salmon skin gelatin within the $<1 \mathrm{kDa}$ UF fraction had DPP-IV inhibition rate of $61.2 \%$, although the $>2.5$ and $1-2.5 \mathrm{kDa}$ fractions demonstrated inhibition rates of 29.6 and $43.2 \%$, respectively [19]. Fraction of $<1.5$ $\mathrm{kDa}$ of gelatin hydrolysate from skin of halibut by E/S ratio $5 \%$ and 4 hours hydrolysis time was $38.2 \%$, which was slightly higher than fraction from skin of hake but insignificant difference $(\mathrm{p}<0.05)$. Furthermore, fraction of $<1.5 \mathrm{kDa}$ of gelatin hydrolysate derived from skin of tilapia by E/S ratio $6 \%$ and 6 hours of hydrolysis period was $51.2 \%$ and it was significant difference $(\mathrm{p}<0.05)$ compared fraction of milkfish skin hydrolysate which was higher than UF fraction of hake and halibut, but lower than UF fraction of tilapia. All of those fractions were originated from gelatin hydrolysis using Flavourzyme [16] 


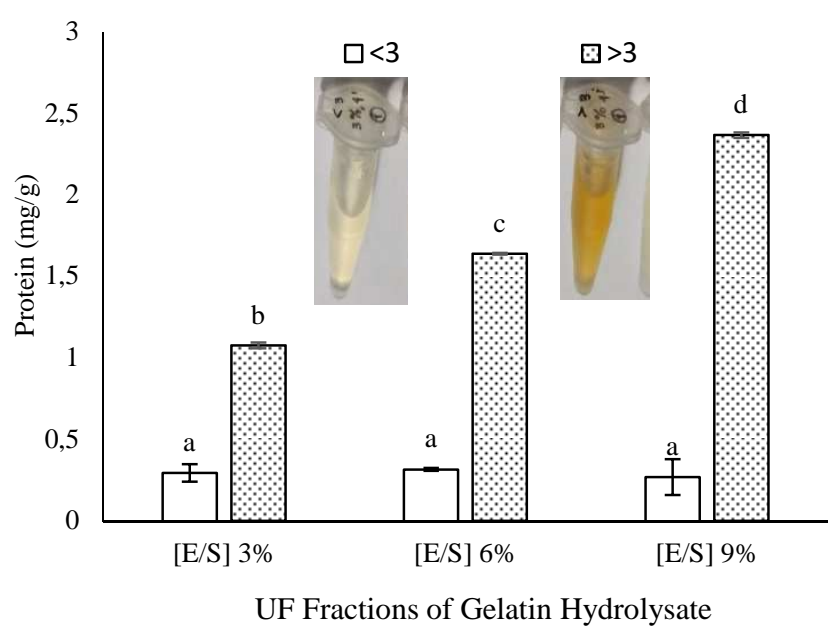

Fig. 6 Protein concentration of UF fraction of fish bone gelatin hydrolysate (at 4 hours hydrolysis). Bovine serum albumin (BSA) at $0.1-1.0 \mathrm{mg} / \mathrm{mL}$ used as standard. Bars with different letters are significantly different at $\mathrm{p}<$ 0.05 .

In addition, the inhibition rate is not the only one of key factor to determine and discover a bioactivities of peptide, while the other important is protein concentration. It was used as base on effectivity establishment of bioactive peptide. The peptide with high bioactivities value and low of protein content is preferable [38]. So that, in this study also quantified the protein concent of UF fractions. The protein concentration has been measured on various $\mathrm{E} / \mathrm{S}$ ratio of concentration at the similar time of hydrolysis (4 hours). Time of hydrolysis for 4 hours was selected regarding their superiority in resulting of hydrolysate as well as UF fraction. Fig. 6 presents the total protein of fraction of gelatin hydrolysate from bone of Indonesian Pangasius catfish and the solution pictures.

Fig. 6 illustrated that protein content in UF fractions $>3$ $\mathrm{kDa}$ were cosiderably higher than UF fractions $\leq 3 \mathrm{kDa}$. The fraction $>3 \mathrm{kDa}$ fish bone hydrolyate from $\mathrm{E} / \mathrm{S}$ ratio $9 \%$ and 4 hours hydrolysis time namely $2.36 \mathrm{mg} / \mathrm{g}$. It was higher and siginificant different $(\mathrm{p}<0.05)$ than other fractions of hydrolyate from different $\mathrm{E} / \mathrm{S}$ ratio (3 and $6 \%$, at 4 hours hydrolysis). Based on these facts, we definitely agreed that, generally, DPP-IV inhibitory activity of a compound or a protein is depend on the protein composition. Li-Chan et al. concluded that the inhibition activity of bioactive peptide from fish gelatin hydrolysate influced by their amino acid composition, molecular weight and hydrophobicity [19]. In addition, Huang et al. mentioned that the inhibition rate of tuna juice hydrolysates against DPP-IV were determined by composition and sequence of amino acid but not the length of peptide [34]. Gelatin hydrolysates derived from warmwater fish possessed better in vitro and in vivo DPP-IV inhibitory activity than those of cold-water fish [16].

Sort of contradiction showed in this study where are the smaller fractions $(\leq 3 \mathrm{kDa})$ have lower inhibition rate than fraction of $>3 \mathrm{kDa}$. Whilst the opposite condition was happened on most of past studies, where are the smaller fraction present highest inhibitory activity. For instance; the inhibition rate of UF fraction $<1.5 \mathrm{kDa}$ from fish skin hydrolysate of nila, hake, halibut and tilapia were about 40$60 \%$, at the same time their UF fraction 1.5-2.5 kDa and $>2.5 \mathrm{kDa}$ were below $20 \%$ [16]. Then, the UF fraction $<1.5 \mathrm{kDa}$ from gelatin hydrolysate of salmon skin was over $60 \%$, while they UF fraction $1.5-2.5 \mathrm{kDa}$ and $>2.5 \mathrm{kDa}$ were below $50 \%$ and around $30 \%$ [19], respectively. Thus, the statement related the correlation between the molecular weight (MW) with DPP-IV inhibition can not be fully accepted. In addition, study operated by Huang et al. (2014) which is using porcine gelatin hydrolysate was described that fraction $<1.5 \mathrm{kDa}$ and $1.5-2.5 \mathrm{kDa}$ had similar inhibition rate of $35 \%$ roughly [39]. Study conducted by $\mathrm{Hsu}$ et al. (2013) found that inhibition rate of fraction 1.5-2.5 kDa from porcine gelatin hydrolysate was slightly higher than fraction $<1.5 \mathrm{kDa}[40]$. Therefore, it will strengthening and persuing the theory toward role of amino acid composition and sequence on DPP-IV inhibitory activity and eliminating the effect of MW.

\section{DPP-IV Inhibitory Activity of GF fraction}

The UF fraction $>3 \mathrm{kDa}$ (from $\mathrm{E} / \mathrm{S}$ ratio $9 \%$ ) has the higher activity, so this fraction was separated further. Each eluted solution from gel filtration sephadex G-25 coloumn was collected and then measured for their protein profile. Figure 7 depicts the protein profile of seventy subfraction which is eluted from gel filtration stage. Based on the protein profile, it is known that the protein began appeared in the 13th subfraction, and then dropped again in the subfraction number of 50. There was no identification at all in the subfraction above 60. Therefore, the subfraction collected that is, starting from the 13th to the 60th number which is divided into five gel filtration (GF) fractions namely F1-F5. Each fractions then quantified their activity as DPP-IV inhibitors. The activity of GF fraction againts DPP-IV presented in Figure 8.

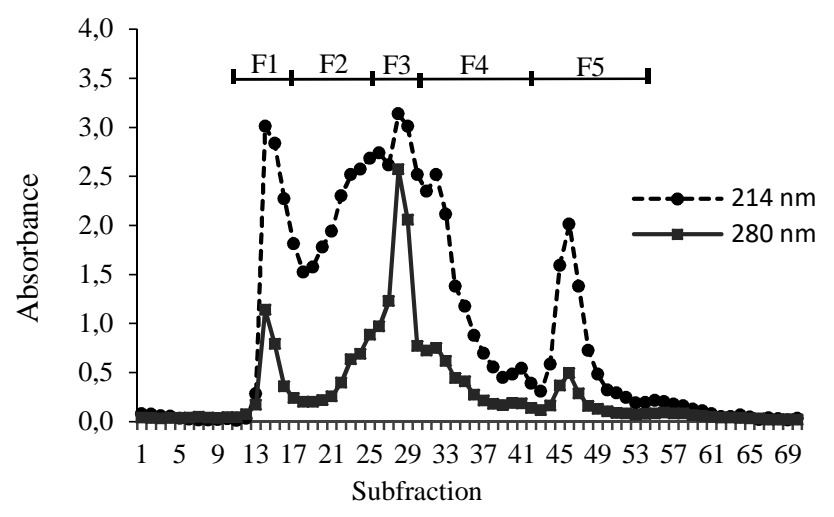

Fig. 7 Elusion profile UF fraction $>3 \mathrm{kDa}$ from E/S ratio $9 \%$ and 4 hours hydrolysis separated with gel filtration coloumn on Sephadex G-25. F1= subfraction number $13-18, \mathrm{~F} 2=$ no. $19-27, \mathrm{~F} 3=$ no. $28-31, \mathrm{~F} 4=$ no. $32-43$ and $\mathrm{F} 5=$ no. 44-60.

The inhibitory activity of GF fraction in this study is in range of $11.08-25.10 \%$ (using $0.1 \mathrm{ng} / \mathrm{mL}$ sitagliptin as standard) and $8.01-20.92 \%$ (using $10 \mu \mathrm{g} / \mathrm{mL}$ diprotin A as standard). The inhibitory activity of these fraction was lower than UF fraction. The main factor that might be influence this slightly reduction fact is the gelatin hydrolysate/polypeptide concentration, where are in the UF fraction, the liquid fraction more concentrated, while in the GF fraction, the solution is aquaeous or thinner because 
aquabidest addition as mobile phase. Study by Huang et al. found that the GF fraction of protein derived from tuna was below $10 \%$ until reach a peak at $39.5 \%$ [34]. In addition, the purified fraction of gelatin hydrolysate derived from salmon skin and porcine gelatin were around $15 \%-68 \%$ and 26.7 $64.6 \%$. However, these gelatin fractions are fractionated and eluted using high performance coloumn chromatography (HPLC) instrument [19], [40].

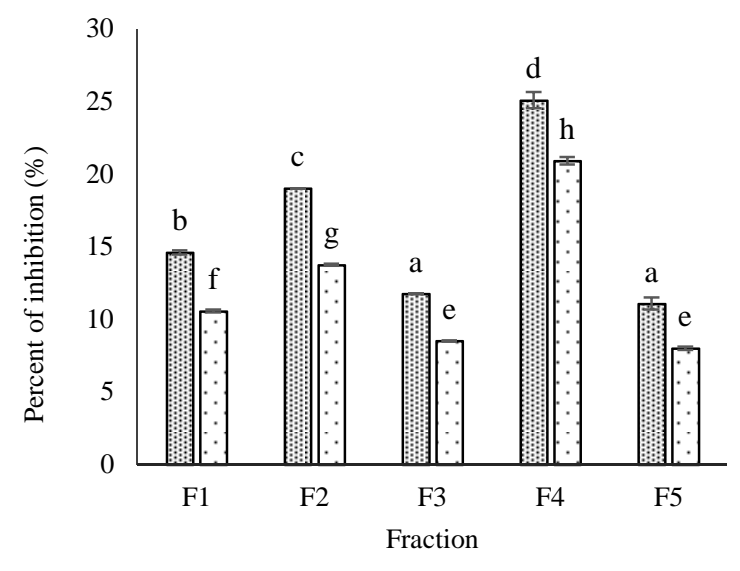

由 Sitagliptin $(0.1 \mathrm{ng} / \mathrm{mL}) \quad$ 口Diprotin A $(10 \mu \mathrm{g} / \mathrm{mL})$

Fig. 8 DPP-IV inhibition activity gel filtration (GF) fraction separated using Sephadex G-25. Percent of inhibition quantified by two standard; Sitagliptin $(0.1 \mathrm{ng} / \mathrm{mL})$ and Diprotin A $(10 \mu \mathrm{g} / \mathrm{mL})$. Bars with different letters are significantly different at $\mathrm{p}<0.05$.

\section{CONCLUSIONS}

This study has clearly demonstrated UF and GF fractions of fish bone gelatin hydrolysate have activity as inhibitor of DPP-IV. The UF fraction $>3 \mathrm{kDa}$ which are hydrolyzed by E/S ratio of $9 \%$ for 4 hours incubation time and GF fraction 4 (F4) were potent as an inhibitor agent of DPP-IV. This study provides an outlook on the gelatin hydrolysates from bone of Pangasius catfish whereas it was the greates source of gelatin with high gelatin and extraction yield as well as superior physico-chemical characteristic.

\section{ACKNOWLEDGMENT}

We would like to acknowledge Ministry Research, Technology and Higher Education of Indonesia (RistekDIKTI) for the research grant. Thank to Dita Fitriani for her technical assistance

\section{REFERENCES}

[1] S. Chakrabarti, S. Guha, and K. Majumder, "Food-Derived Bioactive Peptides in Human Health :," Nutrients, vol. 10, no. 11, pp. 1-17, 2018.

[2] J. L. Díaz-gómez, F. Castorena-torres, and R. E. Preciado-ortiz, "Anti-Cancer Activity of Maize Bioactive Peptides," Front Chem., vol. 5, no. June, pp. 1-8, 2017.

[3] M. E. Oseguera-Toledo, E. González de Mejía, R. Reynoso-Camacho, A. Cardador-Martínez, and S. L. Amaya-Llano, "Proteins and bioactive peptides," Nutrafoods, vol. 13, no. 4, pp. 147-157, 2014.

[4] P. Patil, S. Mandal, S. K. Tomar, and S. Anand, "Food proteinderived bioactive peptides in management of type 2 diabetes," Eur. $J$. Nutr., vol. 54, no. 6, pp. 863-880, 2015.

[5] A. B. Nongonierma and R. J. FitzGerald, "Prospects for the management of type 2 diabetes using food protein-derived peptides with dipeptidyl peptidase IV (DPP-IV) inhibitory activity," Curr. Opin. Food Sci., vol. 8, pp. 19-24, 2016.
[6] K. Kazakos, "Incretin effect: GLP-1, GIP, DPP4," Diabetes Res. Clin. Pract., vol. 93, pp. S32-S36, 2011.

[7] Y. Zhang, R. Chen, H. Ma, and S. Chen, "Isolation and Identification of Dipeptidyl Peptidase IV-Inhibitory Peptides from Trypsin/Chymotrypsin-Treated Goat Milk Casein Hydrolysates by 2D-TLC and LC-MS/MS," J. Agric. Food Chem., vol. 63, no. 40, pp. $8819-8828,2015$.

[8] A. B. Olokoba, O. A. Obateru, and L. B. Olokoba, "Type 2 Diabetes Mellitus: A Review of Current Trends," Oman Med. J., vol. 27, no. 4, pp. 269-273, 2012.

[9] D. A. Tatosian et al., "Dipeptidyl peptidase-4 inhibition in patients with type 2 diabetes treated with saxagliptin, sitagliptin, or vildagliptin," Diabetes Ther., vol. 4, no. 2, pp. 431-442, 2013.

[10] A. B. Nongonierma, L. Dellafiora, S. Paolella, G. Galaverna, P. Cozzini, and R. J. FitzGerald, "In silico approaches applied to the study of peptide analogs of Ile-Pro-Ile in relation to their dipeptidyl peptidase IV inhibitory properties," Front. Endocrinol. (Lausanne)., vol. 9, no. JUN, pp. 1-15, 2018.

[11] P. A. Harnedy and R. J. FitzGerald, "Bioactive peptides from marine processing waste and shellfish: A review," J. Funct. Foods, vol. 4, no. 1, pp. 6-24, 2012.

[12] Y. Atma and H. Ramdhani, "Gelatin extraction from the indigenous Pangasius catfish bone using pineapple liquid waste," Indones. J. Biotechnol., vol. 22, no. 2, p. 86, 2017.

[13] A. A. Mariod and H. F. Adam, "Review: Gelatin, source, extraction and industrial applications," Acta Sci. Pol. Technol. Aliment., vol. 12, no. 2, pp. 135-147, 2013.

[14] I. M. E. Lacroix and E. C. Y. Li-Chan, "Comparison of the susceptibility of porcine and human dipeptidyl-peptidase IV to inhibition by protein-derived peptides," Peptides, vol. 69, pp. 19-25, 2015 .

[15] Y. Atma et al., "The proportion-ratio on dipeptidyl aminopeptidase-4 (DP-4) inhibition by gelatin compared to synthetic sitagliptin," $J$. Immunoass. Immunochem., vol. 40, no. 4, 2019.

[16] T. Y. Wang, C. H. Hsieh, C. C. Hung, C. L. Jao, M. C. Chen, and K. C. Hsu, "Fish skin gelatin hydrolysates as dipeptidyl peptidase IV inhibitors and glucagon-like peptide-1 stimulators improve glycaemic control in diabetic rats: A comparison between warm- and cold-water fish," J. Funct. Foods, vol. 19, pp. 330-340, 2015.

[17] R. Jeya Shakila, E. Jeevithan, A. Varatharajakumar, G. Jeyasekaran, and D. Sukumar, "Functional characterization of gelatin extracted from bones of red snapper and grouper in comparison with mammalian gelatin," LWT - Food Sci. Technol., vol. 48, no. 1, pp. 30-36, 2012.

[18] C. H. Hsieh, T. Y. Wang, C. C. Hung, M. C. Chen, and K. C. Hsu, "Improvement of glycemic control in streptozotocin-induced diabetic rats by Atlantic salmon skin gelatin hydrolysate as the dipeptidylpeptidase IV inhibitor," Food Funct., vol. 6, no. 6, pp. 1887-1892, 2015.

[19] E. C. Y. Li-chan, S. Hunag, C. Jao, K. Ho, and K. Hsu, "Peptides Derived from Atlantic Salmon Skin Gelatin as Dipeptidyl-peptidase IV Inhibitors," J. Agric. Food Chem., vol. 60, no. 4, pp. 973-978, 2012.

[20] M. C. Gomez-Guillen, B. Gimenez, M. E. Lopez-Caballero, and M. P. Montero, "Functional and bioactive properties of collagen and gelatin from alternative sources: A review," Food Hydrocoll., vol. 25, no. 8, pp. 1813-1827, 2011.

[21] F. Mahmoodani, V. S. Ardekani, S. F. See, S. M. Yusop, and A. S. Babji, "Optimization and physical properties of gelatin extracted from pangasius catfish (Pangasius sutchi) bone," J. Food Sci. Technol., vol. 51, no. 11, pp. 3104-3113, 2014.

[22] Y. Atma, "Amino acid and proximate composition of fish bone gelatin from different warm-water species: A comparative study," in IOP Conf Ser: Earth Environ Sci., 2017, vol. 58, no. 012008, pp. 1-5.

[23] Y. Atma et al., "The hydroxyproline content of fish bone gelatin from Indonesian Pangasius catfish by enzymatic hydrolysis for producing the bioactive peptide," Biofarmasi J. Nat. Prod. Biochem., vol. 16, no. 2, pp. 64-68, 2018.

[24] J. M. Koli, S. Basu, B. B. Nayak, S. B. Patange, A. U. Pagarkar, and V. Gudipati, "Functional characteristics of gelatin extracted from skin and bone of Tiger-toothed croaker (Otolithes ruber) and Pink perch (Nemipterus japonicus)," Food Bioprod. Process., vol. 90, no. 3, pp. 555-562, 2012.

[25] Y. Atma, H. Ramdhani, A. Z. Mustopa, M. Pertiwi, and R. Maisarah, "Karakteristik Fisikokimia Gelatin Tulang Ikan Patin (Pangasius sutchi) Hasil Ekstraksi Menggunakan Limbah Buah Nanas (Ananas comosus)," Agritech, vol. 38, no. 1, p. 56, 2018. 
[26] F. Mahmoodani, M. Ghassem, A. S. Babji, S. M. Yusop, and R. Khosrokhavar, "ACE inhibitory activity of pangasius catfish (Pangasius sutchi) skin and bone gelatin hydrolysate," J. Food Sci. Technol., vol. 51, no. 9, pp. 1847-1856, 2014.

[27] K. Kojima, T. Ham, and T. Kato, "Rapid Chromatographic Purification of Dipeptidyl Peptidase IV in Human Submaxillary Gland," J. Chromatogr., vol. 189, no. 2, pp. 233-240, 1980.

[28] A. Da Trindade Alfaro, C. Simões Da Costa, G. Graciano Fonseca, and C. Prentice, "Effect of extraction parameters on the properties of gelatin from king weakfish (Macrodon ancylodon) Bones," Food Sci. Technol. Int., vol. 15, no. 6, pp. 553-562, 2009.

[29] A. Taheri, A. M. Abedian Kenari, A. Gildberg, and S. Behnam, "Extraction and physicochemical characterization of greater lizardfish (Saurida tumbil) skin and bone gelatin," J. Food Sci., vol. 74, no. 3, pp. 160-165, 2009.

[30] F. Zhang, S. Xu, and Z. Wang, "Pre-treatment optimization and properties of gelatin from freshwater fish scales," Food Bioprod. Process., vol. 89, no. 3, pp. 185-193, 2011.

[31] H. Y. Liu, J. Han, and S. D. Guo, "Characteristics of the gelatin extracted from Channel Catfish (Ictalurus Punctatus) head bones," LWT - Food Sci. Technol., vol. 42, no. 2, pp. 540-544, 2009.

[32] S. H. Cho, M. L. Jahncke, K. B. Chin, and J. B. Eun, "The effect of processing conditions on the properties of gelatin from skate (Raja Kenojei) skins," Food Hydrocoll., vol. 20, no. 6, pp. 810-816, 2006.

[33] J. H. Muyonga, C. G. B. Cole, and K. G. Duodu, "Extraction and physico-chemical characterisation of Nile perch (Lates niloticus) skin and bone gelatin," Food Hydrocoll., vol. 18, no. 4, pp. 581-592, 2004.
[34] S. L. Huang, C. L. Jao, K. P. Ho, and K. C. Hsu, "Dipeptidylpeptidase IV inhibitory activity of peptides derived from tuna cooking juice hydrolysates," Peptides, vol. 35, no. 1, pp. 114-121, 2012.

[35] R. Liu, J. Cheng, and H. Wu, "Discovery of food-derived dipeptidyl peptidase IV inhibitory peptides: A review," Int. J. Mol. Sci., vol. 20, no. 3, p. E463, 2019.

[36] A. B. Nongonierma and R. J. FitzGerald, "Dipeptidyl peptidase IV inhibitory properties of a whey protein hydrolysate: Influence of fractionation, stability to simulated gastrointestinal digestion and food-drug interaction," Int. Dairy J., vol. 32, no. 1, pp. 33-39, 2013.

[37] J. Davis et al., "Nature of action of sitagliptin, the dipeptidyl peptidase-IV inhibitor in diabetic animals," Indian J. Pharmacol., vol. 42, no. 4, p. $229,2010$.

[38] C. Jao, C. Hung, Y. Tung, P. Lin, M. Chen, and K. Hsu, "Review article The development of bioactive peptides from dietary proteins as a dipeptidyl peptidase IV inhibitor for the management of type 2 diabetes," BioMedicine, vol. 5, no. 3, pp. 9-15, 2015.

[39] S. Huang, C. Hung, C. Jao, Y. Tung, and K. Hsu, "Porcine skin gelatin hydrolysate as a dipeptidyl peptidase IV inhibitor improves glycemic control in streptozotocin-induced diabetic rats," J. Funct. Foods, vol. 11, no. 91, pp. 235-242, 2014.

[40] K. Hsu, Y. Tung, S. Huang, and C. Jao, "Dipeptidyl Peptidase-IV Inhibitory Activity of Peptides in Porcine Skin Gelatin Hydrolysates," in Bioactive Food Peptides in Health and Disease, no. 2, B. Hernandez-Ledesma and C. C. Hsieh, Eds. London: Intech, 2013, pp. 205-218. 